\title{
Assessment of the effect of calcium dobesilate in experimental liver ischemia-reperfusion injury
}

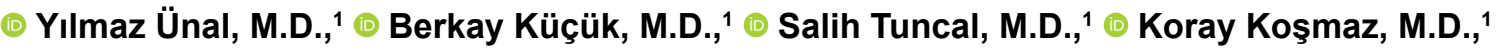 \\ Nadir Turgut Çavuşoğlu, M.D., ${ }^{1}$ @ Kemal Kısmet, M.D., ${ }^{1} \odot$ Mehmet Şeneş, M.D., ${ }^{2}$ \\ (D) Pınar Celepli, M.D., ${ }^{3}$ @ Murat Durak, M.D., ${ }^{2}$ @ Sema Hücümenoğlu, M.D. ${ }^{3}$
}

\author{
'Department of General Surgery, Ankara Training and Research Hospital, Ankara-Turkey \\ ${ }^{2}$ Department of Biochemistry, Ankara Training and Research Hospital, Ankara-Turkey \\ ${ }^{3}$ Department of Pathology, Ankara Training and Research Hospital, Ankara-Turkey
}

\begin{abstract}
BACKGROUND: This study investigates the protective effect of calcium dobesilate (CaDob), an effective antioxidant and anti-inflammatory drug, on experimental liver ischemia-reperfusion injury (IRI).

METHODS: Forty rats were divided into four groups. In Group I, (sham), only hepatic pedicle was induced. In Group 2 (control), hepatic pedicle was reperfused for $90 \mathrm{~min}$ after being clamped for $60 \mathrm{~min}$. No treatment was given in Group I and 2. In Group 3 (perioperative $\mathrm{CaDob}$ ), $100 \mathrm{mg} / \mathrm{kg}$ CaDob was given 2 hours prior to the operation in which hepatic pedicle was reperfused for 90 min following a 60-min clamp. In Group 4 (preoperative CaDob), after $100 \mathrm{mg} / \mathrm{kg} / \mathrm{day} \mathrm{CaDob}$ was given for 10 days before the operation, hepatic pedicle was clamped for $60 \mathrm{~min}$ and reperfused for 90 minutes. At the end of these procedures, blood and liver tissue samples were collected for biochemical and histopathological assessment.
\end{abstract}

RESULTS: Liver function tests and tissue oxidative stress parameters were significantly lower in the preoperative and perioperative treatment groups than the control group. Furthermore, it was observed that histopathological injury in the control group significantly decreased in both perioperative and preoperative treatment groups.

CONCLUSION: Calcium dobesilate demonstrated a significant hepatoprotective effect in terms of its antioxidant and anti-inflammatory effects.

Keywords: Calcium dobesilate; experimental; histopathology; ischemia reperfusion; liver; oxidative stress.

\section{INTRODUCTION}

Ischemia reperfusion injury (IRI) is a clinical situation with significant effects on multiple organs including the liver, heart, intestine, kidney and brain. ${ }^{[1]}$ Hepatic IRI is an important problem that arises during liver resection, liver trauma operation, organ transplantation and reconstructive vascular surgery and it is a life-threatening situation. ${ }^{[2]}$ Moreover, apart from surgical interventions, hepatic IRI can also appear due to hemorrhagic shock and sepsis. ${ }^{[3]}$ During the ischemic period, cellular damage is observed in tissues exposed to ischemia due to oxygen deprivation. Reactive oxygen species (ROS) are released from ischemic tissues upon the return of blood flow (reperfusion) and this leads to more serious organ damage. ${ }^{[4]}$ In hepatic IRI pathogenesis; numerous complex and multifactorial reasons play a role, such as microcirculation dysfunction, the activation of Kuppfer cells, apoptosis, sinusoidal endothelium cell dysfunction, oxidative stress and inflammation. ${ }^{[5]}$ Hepatic IRI leads to serious hepatic pathologic reactions resulting in cellular death and organ dysfunction. Different mechanisms play a part in hepatic cellular damage during ischemia and also after reperfusion. Although it is not known which mechanism is important in the pathogenesis of ischemic cellular damage, oxygen deprivation is the most

Cite this article as: Ünal Y, Küçük B, Tuncal S, Koşmaz K, Çavuşoğlu NT, Kısmet K, et al. Assessment of the effect of calcium dobesilate in experimental liver ischemia-reperfusion injury. Ulus Travma Acil Cerrahi Derg 2018;24:391-397.

Address for correspondence: Yılmaz Ünal, M.D.

Ankara Eğitim ve Araştırma Hastanesi, Genel Cerrahi Kliniği, Ankara, Turkey

Tel: +90 312 - 5953000 E-mail: yilmazunal66@mynet.com

Ulus Travma Acil Cerrahi Derg 2018;24(5):39I-397 DOI: 10.5505/tjtes.2018.33238 Submitted: 19.04.2018 Accepted: 13.08.2018 Online: 20.09.2018

Copyright 2018 Turkish Association of Trauma and Emergency Surgery 
commonly suspected factor. During ischemia, multiple different cellular and subcellular dysfunctions in cell membranes and decreased protein synthesis arise. Although several experimental studies have been carried out to prevent or decrease hepatic IRI, there is still no agent commonly used in clinical practice. ${ }^{[6-8]}$

Calcium dobesilate is a pharmacological agent used in the treatment of chronic venous stasis, diabetic retinopathy and hemorrhoidal diseases due to its angioprotective and antioxidant properties. ${ }^{[9]}$ Moreover, it has been shown in many studies that calcium dobesilate corrects capillary dysfunctions, decreases free oxygen radicals, increases nitric oxide synthase and prevents desquamation in endothelium cells. ${ }^{[10,11]}$ In experimental studies, calcium dobesilate has been shown to have protective effects against ischemia reperfusion injury in various organs like the heart, lungs and intestines. The antioxidant and anti-inflammatory properties of calcium dobesilate are attributed to reduced lipid pre-oxidation caused by free oxygen radicals and a decreased release of inflammatory cytokines, such as platelet activating factor (PAF). ${ }^{[12-14]}$ However, there are no studies in the present literature that investigate the effect of calcium dobesilate on hepatic IRI.

As oxidative stress and inflammation are the main mechanisms responsible for tissue damage in ischemia-reperfusion events, this study was designed to investigate the effect of calcium dobesilate, which has antioxidant and anti-inflammatory effects, on hepatic IRI.

\section{MATERIALS AND METHODS}

The study was performed with the endorsement of the Animal Ethics Committee at Ankara Training and Research Hospital and according to the principles of the National Guidelines for the Use and Care of Laboratory Animals.

\section{Animals}

The study included 40 adult, female Wistar Albino rats in total, each weighing $225 \pm 25 \mathrm{gr}$. The rats were stored in wire cages at a fixed temperature of $21^{\circ} \mathrm{C} \pm 2{ }^{\circ} \mathrm{C}$ with a 12 hour light/dark cycle. The rats in the sample were made to fast for 12 hours and their access to water was stopped 2 hours prior to anesthesia. No rats received parenteral or enteral antibiotics throughout the experiment. The anesthesia and surgical intervention were performed under sterile conditions by the same team. The rats were divided into 4 groups randomly, each consisting of 10 rats. All rats were anesthetized intramuscularly with $50 \mathrm{mg} / \mathrm{kg}$ of ketamine hydrochloride (Ketalar $^{\circledR}$; Parke-Davis, Istanbul, Turkey) and $5 \mathrm{mg} / \mathrm{kg}$ Xylazine (Rompun ${ }^{\circledR}$; Bayer, Istanbul, Turkey).

\section{Experimental Groups and Surgical Procedure}

In all rats, the abdomen was entered with a midline incision and the following procedures were applied to the groups. In
Group I(sham), only hepatic pedicle was induced. In Group 2 (control), ischemia was performed by clamping the hepatic pedicle for $60 \mathrm{~min}$. Following the ischemic period, the clamp was opened and 90 min reperfusion of the liver was provided. In Group I and Group 2, no treatment was applied. In Group 3 (perioperative CaDob), 100 mg/kg calcium dobesilate (Doxium $®$ Abdi Ibrahim, Istanbul, Turkey) was given 2 hours before the operation by using an orogastric tube. Then, ischemia was carried out by clamping the hepatic pedicle for $60 \mathrm{~min}$ and reperfusion was carried out for $90 \mathrm{~min}$ by opening the clamp. In Group 4 (preoperative CaDob), 100 mg/kg/day calcium dobesilate was given for 10 days before the operation through an orogastric tube. At the end of this procedure, the hepatic pedicle was clamped for $60 \mathrm{~min}$ and then reperfusion was carried out for 90 min by opening the clamp.

After the completion of these procedures, all the rats were euthanized using an overdose of ketamine. Following the laparotomy, blood and liver tissue samples were collected for biochemical and histopathological analyses.

\section{Biochemical Analyses}

Evaluation of the liver functions in the serum was carried out in the Biochemistry Department of Ankara Training and Research Hospital. Aspartate aminotransferase (AST), alanine aminotransferase (ALT), alkaline phosphatase (ALP) and gamma glutamyl transpeptidase (GGT) were measured by use of a chemistry analyzer for clinical purposes (Beckman Coulter 5800) which uses Beckman Coulter commercial kits.

The parameters of oxidative stress were evaluated at the Biochemistry Department of Ankara Training and Research Hospital. Liver tissues were kept at $-80^{\circ} \mathrm{C}$ until the day of the analysis. The total sulfhydryl (SH), malondialdehyde (MDA) and fluorescent oxidation products (FOP) levels were determined. MDA acts as a lipid peroxidation indicator and is a known tissue injury index. The levels of MDA were measured through the fluorometric method, in line with the description of Wasowicz et al. ${ }^{[15]}$ Following the reaction that occurs between thiobarbituric acid (TBA) and MDA, the reaction product was isolated in butanol. Following this, a spectrofluorometrical measurement was carried out at a wavelength of $547 \mathrm{~nm}$ for emission and $525 \mathrm{~nm}$ for excitation. The standard was designated as a 0-5 $\mu \mathrm{mol} / \mathrm{L} \mathrm{I,} \mathrm{I',3,3'} \mathrm{tetraethoxypropane}$ solution. $50 \mu \mathrm{L}$ homogenate was introduced into $10 \mathrm{ml}$ tubes made of glass, each with $\mathrm{I} \mathrm{ml}$ of distilled water in order to measure MDA levels in tissue. Then, a $1 \mathrm{~mL}$ solution which contained $29 \mathrm{mmol} / \mathrm{L}$ TBA was added to acetic acid and mixed. Following this, the samples were exposed to heat of between $95^{\circ}$ and $100^{\circ} \mathrm{C}$ for a period of I hour using a water bath. After cooling the heated samples, they were mixed with $25 \mu \mathrm{L}$ of $5 \mathrm{~mol} / \mathrm{L}$ hydrochloric acid $(\mathrm{HCL})$ and agitation was used for a period of 5 min to extract the mixture of the reaction using $3.5 \mathrm{~mL}$-butanol. Following the separation of the butanol phase through centrifugation for $10 \mathrm{~min}$ at 1500 
Table I. Suzuki scoring system

\begin{tabular}{lccc}
\hline Grade & $\begin{array}{c}\text { Sinusoidal } \\
\text { congestion }\end{array}$ & Necrosis & Vacuolization \\
\hline 0 & None & None & None \\
1 & Mild & Simple cell necrosis & Mild \\
2 & Moderate & $0-30 \%$ & Moderate \\
3 & Severe & $30-60 \%$ & Severe \\
4 & Excessive & Over $60 \%$ & Excessive \\
\hline
\end{tabular}

g, a fluorometer (HITACHI F-2500) was used to measure the fluorescence in the butanol extract at $547 \mathrm{~nm}$ and $525 \mathrm{~nm}$ wavelengths for emission and excitation, respectively. Solutions of $0-5 \mu \mathrm{mol} / \mathrm{L} \mathrm{I}, \mathrm{I}^{\prime}, 3,3^{\prime}$ tetraethoxypropane were utilized as standard. The levels of MDA were shown as nmol/g.

It is known that injured tissues have lower total $\mathrm{SH}$ levels than normal ones. The measurement of total $\mathrm{SH}$ was carried out in a spectrophotometrical way by means of the Sedlak and Lindsay ${ }^{[16]}$ method. $250 \mu \mathrm{L}$ of aliquots taken from the supernatant fraction of the homogenized tissue were stirred in tubes of 5 $\mathrm{mL}$ using $50 \mu \mathrm{L}$ of $0.01 \mathrm{M} 5,5$ "-dithiobis (2 nitrobenzoic acid) (DTNB) and $750 \mu \mathrm{l}$ of $0.2 \mathrm{M}$ Tris buffer, $\mathrm{pH}$ 8.2. $3950 \mu \mathrm{l}$ absolute methanol was inserted in order to have a final mixture of $5 \mathrm{ml}$. Also, a sample blank (No DTNB) and a reagent blank (No sample) were obtained in a comparable way. Rubber stoppers were used to close the tubes and color was permitted to develop for a period of $15 \mathrm{~min}$ in the reaction mixture. The resultant mixtures were then put into a centrifuge for $15 \mathrm{~min}$ at about $3,000 \mathrm{~g}$ at normal room temperature. The values of absorbance found in supernatant fractions were identified by means of spectrophotometer at $412 \mathrm{~nm} \cdot{ }^{[16]}$

Homogenized tissues were isolated using ethanol-ether $(3 / \mathrm{I}$, $\mathrm{v} / \mathrm{v}$ ) for FOP measurements; then these tissues were evaluated through a spectrofluorometer at wavelengths of 360 and 430 (wavelengths for excitation/emission). ${ }^{[1]}$

\section{Histopathological Analysis}

The analysis of histopathology was executed at Ankara
Training and Research Hospital, Pathology Department. The liver tissue samples for light microscope analysis were fixed in a 10\% formaldehyde solution for 24 hours. Following the stages of ethanol dehydration and xylene classification, the tissue samples were embedded in blocks of paraffin. $4 \mu \mathrm{m}$ thick sections were cut from the blocks of paraffin with a Leica RM 2I55 RT microtome. These sections of tissues were stained using hematoxylin \& eosin and then analyzed. The histopathological examination was made using a blinded study carried out by a pathologist using a light microscope (Olympus BX5ITF). The histopathological evaluation was completed semi-quantitatively with the modified Suzuki Scoring System ${ }^{[18]}$ from 0 to 4 with respect to sinusoidal congestion, liver cell vacuolization and hepatocyte necrosis. The modified Suzuki Scoring System is given in Table I.

\section{Statistical Analysis}

The Statistical Analysis Package for Social Sciences (SPSS version 15.0) was used to execute data analysis (SPSS Inc., Chicago, IL, USA). According to the analysis, all the variables showed a normal distribution around the average value. The data were given in the form of mean \pm standard deviation. Either the Kruskal-Wallis variance analysis or the ANOVA (One-way analysis of variance) was made use of in order to assess the differences across the groups. In cases when the $P$ value had a statistical significance, the Mann-Whitney $U$ multivariance analysis was employed to find out the differences across the groups. It was accepted that the $p<0.05$ level was statistically significant.

\section{RESULTS}

\section{Liver Function Tests}

The average levels of liver functions (ALT, AST, GGT, ALP) are given in Table 2. A significant difference $(p<0.05)$ was found between the sham and the other three groups in all the parameters (except for the ALP and GGT values in the preoperative $\mathrm{CaDob}$ group). The liver functions had the highest values in the control group. The perioperative and preoperative $\mathrm{CaDob}$ treatment lowered these high levels significantly compared to the control group $(p<0.05)$. Although the levels in the preoperative $\mathrm{CaDob}$ group were significantly lower

Table 2. The average levels of liver functions

\begin{tabular}{|c|c|c|c|c|}
\hline Groups & AST (U/L) & ALT (U/L) & GGT (U/L) & ALP (U/L) \\
\hline Group I (Sham) & $352.90 \pm 108.02^{a, b, c}$ & $173.70 \pm 98.90^{\mathrm{a}, \mathrm{b}, \mathrm{c}}$ & $1.62 \pm 0.74^{\mathrm{a}, \mathrm{b}}$ & $96.20 \pm 17.40^{\mathrm{a}, \mathrm{b}}$ \\
\hline Group 2 (Control) & $2006.66 \pm 422 .{ }^{d, e}$ & $|524.|| \pm 265.0|^{\mathrm{d}, \mathrm{e}}$ & $7.40 \pm 3.47^{\mathrm{d}, \mathrm{e}}$ & $186.80 \pm 36.57^{\mathrm{d}, \mathrm{e}}$ \\
\hline Group 3 (Periop CaDob) & $|452.66 \pm 680.6|$ & $1025.75 \pm 421.27$ & $3.25 \pm 1.58$ & $129.87 \pm 32.57$ \\
\hline Group 4 (Preop CaDob) & $1369.37 \pm 429.77$ & $994.62 \pm 513.35$ & $3.00 \pm 1.73$ & $118.00 \pm 31.76$ \\
\hline
\end{tabular}


Table 3. The average levels of oxidative stress parameters

\begin{tabular}{lccc}
\hline Groups & MDA (nmol/gr protein) & Total SH ( $\boldsymbol{\mu m o l} / \mathbf{g r}$ protein) & FOP (FOP/gr protein) \\
\hline Group I (Sham) & $24.90 \pm 8.5^{\mathrm{a}, \mathrm{b}}$ & $122.47 \pm 17.35^{\mathrm{a}}$ & $100.93 \pm 9.05^{\mathrm{a}, \mathrm{b}, \mathrm{c}}$ \\
Group 2 (Control) & $55.61 \pm 8.26^{\mathrm{d}, \mathrm{e}}$ & $87.29 \pm 8.0 \mathrm{I}^{\mathrm{d}, \mathrm{e}}$ & $193.83 \pm 29.45^{\mathrm{d}, \mathrm{e}}$ \\
Group 3 (Periop CaDob) & $34.63 \pm 9.52$ & $116.36 \pm 28.30$ & $140.29 \pm 24.82$ \\
Group 4 (Preop CaDob) & $28.96 \pm 5.23$ & $120.89 \pm 10.83$ & $131.51 \pm 39.98$ \\
\hline
\end{tabular}

aSignificantly different, sham vs control ( $p<0.05)$, bsignificantly different, sham vs periop $\mathrm{CaDob}(p<0.05)$, 'significantly different, sham vs preop CaDob ( $p<0.05$ ), dsignificantly different, control vs periop CaDob $(p<0.05)$, esignificantly different, control vs preop CaDob ( $p<0.05)$. MDA: Malondialdehyde; SH: Sulfydryl; FOP: Fluorescent oxidation products.

Table 4. The average histopathological scores of the groups

\begin{tabular}{|c|c|c|c|}
\hline Groups & Congestion & Vacuolisation & Necrosis \\
\hline Group I (Sham) & $0.50 \pm 028^{\mathrm{a}, \mathrm{b}}$ & $0.00 \pm 0.00$ & $0.00 \pm 0.00$ \\
\hline Group 2 (Control) & $2.90 \pm 0.56^{\mathrm{c}, \mathrm{d}}$ & $0.20 \pm 0.11$ & $0.00 \pm 0.00$ \\
\hline Group 3 (Periop CaDob) & $1.88 \pm 0.78^{e}$ & $0.00 \pm 0.00$ & $0.00 \pm 0.00$ \\
\hline Group 4 (Preop CaDob) & $0.50 \pm 0.31$ & $0.05 \pm 0.02$ & $0.00 \pm 0.00$ \\
\hline
\end{tabular}

than the perioperative CaDob group, no statistical difference was found between these two groups $(p>0.05)$.

\section{Oxidative Stress Parameters}

The average levels of oxidative stress parameters (MDA, total SH, FOP) are presented in Table 3. Significant differences were found in all the parameters between the sham and the control group $(p<0.05)$. A significant difference was found in MDA and FOP between the sham and the perioperative CaDob group and in FOP between the sham and the preoperative CaDob group $(p<0.05)$.

The highest levels of MDA and FOP and the lowest levels of total $\mathrm{SH}$ were detected in the control group. It was determined that preoperative and perioperative $\mathrm{CaDob}$ treatment significantly decreased the MDA and FOP levels and significantly increased the total $\mathrm{SH}$ level $(p<0.05)$. Although the levels of MDA and FOP were lower and the total SH levels were higher in the preoperative $\mathrm{CaDob}$ group compared to the perioperative $\mathrm{CaDob}$ group, no statistical differences were found between these two groups $(p>0.05)$.

\section{Histopathological Results}

The average histopathological scores of the groups are given in Table 4. The congestion scores of the sham group were significantly lower than the control and perioperative groups $(p<0.05)$. The highest congestion scores were in the control group and it was determined that perioperative and preoperative calcium dobesilate treatment significantly decreased the congestion scores $(p<0.05)$. There was also a significant difference in terms of congestion scores between the perioperative and preoperative calcium dobesilate groups $(p<0.05)$. While there was no significant difference between the groups with respect to vacuolization $(p>0.05)$, necrosis was not detected in any groups.

Typical histopathological changes are given in Figure la, b and c. It was seen that the portal areas and lobules had a regular structure in the sham group. Inflammation and sinusoidal congestion were not observed (Fig. Ia). Intense sinusoidal congestion and inflammatory cell infiltration were observed around the central vein in the control group (Fig. Ib). It was seen that sinusoidal congestion and inflammation decreased in the groups in which preoperative and perioperative $\mathrm{CaDob}$ were given compared to the control group (Fig. Ic).

\section{DISCUSSION}

Ischemia is the inadequate supply of blood as a result of decreased or obstructed blood flow to tissues and organs due to certain reasons. Oxygen deprivation in tissues exposed to ischemia for a certain period of time results in tissue damage. Restoration of blood flow following ischemia is called reperfusion and during this period, tissue damage caused by ischemia further increases because of the release of reactive oxygen species (ROS) from ischemic tissues. ${ }^{[4]}$ This is commonly referred to as IRI and is a serious clinical issue concerning multiple vital organs such as the liver, heart, intestines and kidney. ${ }^{[I]}$ It is thought that the local and systemic effects created by IRI contributes to high morbidity and mortality in 

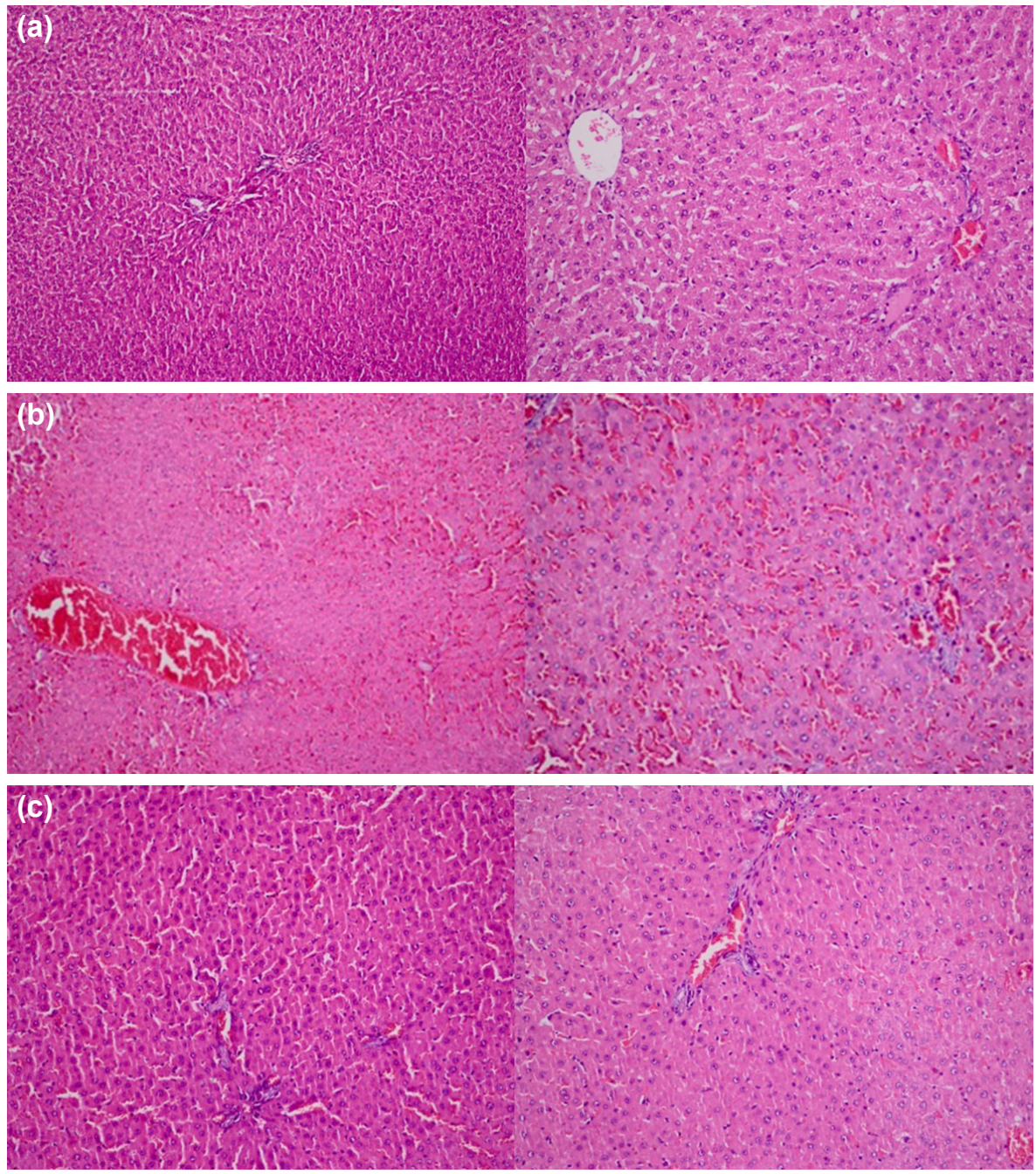

Figure 1. (a) In the sham group, portal areas and lobules are in a regular structure with no inflammation or sinusoidal congestion $(x 100, x 200)$. (b) In the control group, there is an intense sinusoidal congestion and inflammation around the central vein in the liver tissue.(x100, x200). (c) In CaDob groups, the sinusoidal congestion was decreased significantly when compared with control group (x200).

numerous clinical situations like organ transplantation, myocardial infarction, cerebrovascular diseases, major surgical interventions and hemorrhagic shock. ${ }^{[19,20]}$

Hepatic IRI is an important clinical situation which emerges during liver resection, liver trauma operations, liver transplantation and reconstructive vascular surgery. ${ }^{[2]}$ In addition to surgical interventions, hepatic IRI can also appear in such situations as hemorrhagic shock, resuscitation and sepsis. [3] Ischemia is induced in major liver operations through hepatic pedicle clamping to minimize blood loss. Afterwards, the reperfusion period begins by declamping. However, this method may result in hepatic IRI. ${ }^{[21]}$

Numerous complex and multifactorial causes have a role in hepatic IRI pathogenesis, such as microcirculation dysfunction, the activation of Kuppfer cells, apoptosis, sinusoidal endothelium cell dysfunction, oxidative stress and inflam- mation. ${ }^{[5]}$ Microcirculation dysfunction develops in the liver as a result of all these events. The neutrophils and the activation of Kupffer cells lead to the release of free oxygen radicals and inflammatory cytokines. Free oxygen radicals play the most important role in IRI physio-pathogenesis. A small number of free oxygen radicals are produced during metabolism under normal circumstances and thus all aerobic organisms are exposed to physiologic oxidative stress. Normally these radicals are immediately eliminated by the antioxidant defense mechanisms of the body. However, since the intrahepatic defense systems are impaired during hepatic IRI, the excessive numbers of free oxygen radicals produced cannot be removed effectively. Therefore, these free oxygen radicals lead to the peroxidation of unsaturated fatty acids in cell membranes. Moreover, they are cross-linked to biological macromolecules like DNA, RNA and proteins and change their structures, thus resulting in cell death and tissue damage. ${ }^{[22,23]}$ 
Malondialdehyde (MDA) is a byproduct of lipid peroxidation and is a sensitive indicator of oxidative stress damage. ${ }^{[15,24]}$ Additionally, it is also known that injured tissues have lower total $\mathrm{SH}$ levels than normal ones. ${ }^{[16]}$ In this study, significantly lower levels of MDA and FOP, and also higher levels of total $\mathrm{SH}$ were observed in the treatment groups.

Numerous experimental studies have been carried out in order to decrease the harmful effects of hepatic IRI. ${ }^{[6-8,25]}$ However, there is still no pharmacological agent routinely used in clinical practice.

In a study designed by Tanrikulu et al., ${ }^{[6]}$ it was determined that diosmin treatment significantly reduced oxidative stress parameters and liver enzyme levels in an experimental IRI model in rats. Furthermore, diosmin ameliorated the histopathological abnormalities caused by hepatic IRI. In another experimental liver IRI model carried out by Deng et al., ${ }^{[8]}$ it was shown that melatonine effectively decreased both the levels of liver functions and free oxygen radicals.

Barlas et al. ${ }^{[25]}$ investigated the effect of erdosteine on experimental liver IRI and found that erdosteine treatment relieved histopathological findings compared to the control group. Moreover, it was determined that this treatment improved liver function values and oxidative stress parameters.

Calcium dobesilate, a synthetic sulfobenzene derivative, is an angio-protective and venotonic pharmacological agent used orally. It is widely used in clinical practice in the treatment of chronic venous stasis, hemorrhoidal diseases and diabetic retinopathy. ${ }^{[9]}$ Moreover, it has been shown in various studies that calcium dobesilate has antioxidant, antiaggregant and endothelium function regulating effects. It reduces capillary permeability and blood viscosity with its antiaggregant and antioxidant effects and increases lymphatic drainage. These studies have shown that calcium dobesilate increases endothelial nitric oxide synthesis through nitric oxide synthetase activation. ${ }^{[10,11]}$ Calcium dobesilate carries out its antiaggregant activity through cyclic adenosine monophosphate (cAMP) with the activation of the adenylate cyclase enzyme. Furthermore, it performs an antioxidant effect by reducing the release of platelet activating factor (PAF) from platelets and by eliminating free oxygen radicals that activate endothelium damage. ${ }^{[26,27]}$

Seker et al. ${ }^{[14]}$ investigated the effects of calcium dobesilate on intestinal IRI in rats and they determined that calcium dobesilate increased the total antioxidant capacity, reduced tissue damage histopathologically and decreased both the serum and tissue oxidative stress index.

In another experimental study performed by Cihan Ozbek et al., ${ }^{[12]}$ it was found that calcium dobesilate had a cardioprotective effect on rat hearts perfused with calcium dobesilate.
Garay et al. ${ }^{[27]}$ revealed that in addition to its strong antioxidant properties, calcium dobesilate improved diabetic endothelium dysfunction, reduced apoptosis and decreased vascular cell proliferation. In another study by Jafarey et al., ${ }^{[28]}$ it was found that calcium dobesilate protected rats against nephrotoxicity related to gentamicin. Brunet et al. ${ }^{[29]}$ determined that calcium dobesilate reduced microvascular permeability increased by free oxygen radicals in rats. Moreover, they concluded that this angioprotective effect might be related to the antioxidant activity of calcium dobesilate.

Based on these studies which show the strong antioxidant properties and the positive effects of calcium dobesilate on IRI, the present study investigated its protective effects on experimental liver IRI. When the results of this study are examined, it can be seen that preoperative and perioperative calcium dobesilate treatment significantly reduced sinusoidal congestion and inflammation in liver tissue compared to the control group. Additionally, serum liver functions and tissue oxidative stress parameters were significantly decreased in the treatment groups. The results in the preoperative treatment group were more positive than the perioperative treatment group but the difference between these two groups was not statistically significant.

\section{Conclusion}

To the best of our knowledge, this is the first study in the literature that investigates the effect of calcium dobesilate on hepatic IRI. In our study, perioperative and preoperative calcium dobesilate treatment showed a strong hepatoprotective effect due to its antioxidant and anti-inflammatory properties. According to the results of this study, calcium dobesilate can be used as a protective agent for IRI in both emergent and elective liver surgery.

\section{Conflict of interest: None declared.}

\section{REFERENCES}

1. McCord JM. Oxygen-derived free radicals in postischemic tissue injury. N Engl J Med 1985;31:159-63.

2. Glantzounis GK, Salacinski HJ, Yang W, Davidson BR, Seifalian AM. The contemporary role of antioxidant therapy in attenuating liver ischemia-reperfusion injury: a review. Liver Transpl 2005;11:1031-47.

3. Powner DJ. Factors during donor care that may affect liver transplantation outcome. Prog Transplant 2004;14:241-9. [CrossRef]

4. Pantazi E, Bejaoui M, Folch-Puy E, Adam R, Roselló-Catafau J. Advances in treatment strategies for ischemia reperfusion injury. Expert Opin Pharmacother 2016;17:169-79. [CrossRef]

5. Selzner N, Rudiger H, Graf R, Clavien PA. Protective strategies against ischemic injury of the liver. Gastroenterology 2003;125:917-36.

6. Tanrikulu Y, Sahin M, Kismet K, Kilicoglu SS, Devrim E, Tanrikulu CS, et al. The protective effect of diosmin on hepatic ischemia reperfusion injury: an experimental study. Bosn J Basic Med Sci 2013;13:218-24.

7. Yucel AF, Pergel A, Aydin I, Alacam H, Karabicak I, Kesicioglu T, et al. Effect of infliximab on acute hepatic ischemia/ reperfusion injury in rats. Int J Clin Exp Med 2015;8:21287-94. 
8. Deng WS, Xu Q, Liu YE, Jiang CH, Zhou H, Gu L. Effects of melatonin on liver function and lipid peroxidation in a rat model of hepatic ischemia/reperfusion injury. Exp Ther Med 2016;11:1955-60. [CrossRef]

9. Allain H, Ramelet AA, Polard E, Bentué-Ferrer D. Safety of calcium dobesilate in chronic venous disease, diabetic retinopathy and haemorrhoids. Drug Saf 2004;27:649-60. [CrossRef]

10. Ruiz E, Lorente R, Tejerina T. Effects of calcium dobesilate on the synthesis of endothelium-dependent relaxing factors in rabbit isolated aorta. Br J Pharmacol 1997;121:711-6. [CrossRef]

11. Suschek C, Kolb H, Kolb-Bachofen V. Dobesilate enhances endothelial nitric oxide synthase-activity in macro- and microvascular endothelial cells. Br J Pharmacol 1997;122:1502-8. [CrossRef]

12. Cihan Ozbek I, Arslan C, Cantürk E, Süzer O. The effects of calcium dobesilate on the mechanical function of rat hearts. J Cardiovasc Surg 2009;50:395-401.

13. Bozkurt AK, Konukoğlu D, Ustündağ N, Yüceyar L, Mayda AS. Calcium dobesilate ameliorates lung injury following lower limb ischemia/reperfusion. Drugs Exp Clin Res 2002;28:127-32.

14. Seker A, Bardakci O, Eryilmaz S, Kocarslan S, Incebiyik A, Yucel Y, et al. Does calcium dobesilate protect against intestinal ischemia-reperfusion injury induced in rats? Eur Rev Med Pharmacol Sci 2016;20:2168-73.

15. Wasowicz W, Nève J, Peretz A. Optimized steps in fluorometric determination of thiobarbituric acid-reactive substances in serum: importance of extraction $\mathrm{pH}$ and influence of sample preservation and storage. Clin Chem 1993;39:2522-6.

16. Sedlak J, Lindsay RH. Estimation of total, protein-bound, and nonprotein sulfhydryl groups in tissue with Ellman's reagent. Anal Biochem 1968;25:192-205. [CrossRef]

17. Wu T, Willett WC, Rifai N, Rimm EB. Plasma fluorescent oxidation products as potential markers of oxidative stress for epidemiologic studies. Am J Epidemiol 2007;166:552-60. [CrossRef]

18. Suzuki S, Toledo- Pereyra LH, Rodriguez FJ, Cejalvo D. Neutrophil infiltration as an important factor in liver ischemia and reperfusion in- jury. Modulating effects of FK506 and cyclosporine. Transplantation 1993;55:1265-72. [CrossRef]

19. Serracino-Inglott F, Habib NA, Mathie RT. Hepatic ischemia-reperfusion injury. Am J Surg 2001;181:160-6. [CrossRef]

20. Jaeschke H. Molecular mechanisms of hepatic ischemia-reperfusion injury and preconditioning. Am J Physiol Gastrointest Liver Physiol 2003;284:G15-26. [CrossRef]

21. Jin LM, Jin SF, Liu YX, Zhou L, Xie HY, Yan S, et al. Ischemic preconditioning enhances hepatocyte proliferation in the early phase after ischemia under hemi-hepatectomy in rats. Hepatobiliary Pancreat Dis Int 2012;11:521-6. [CrossRef]

22. Elias-Miró M, Jiménez-Castro MB, Rodés J, Peralta C. Current knowledge on oxidative stress in hepatic ischemia/reperfusion. Free Radic Res 2013;47:555-68. [CrossRef]

23. van Golen RF, van Gulik TM, Heger M. Mechanistic overview of reactive species-induced degradation of the endothelial glycocalyx during hepatic ischemia/reperfusion injury. Free Radic Biol Med 2012;52:1382-402.

24. Del Rio D, Stewart AJ, Pellegrini N. A review of recent studies on mal-ondialdehyde as toxic molecule and biological marker of oxidative stress. Nutr Metab Cardiovasc Dis 2005;15:316-28. [CrossRef]

25. Barlas AM, Kismet K, Erel S, Kuru S, Cavusoglu T, Senes M, et al. Erdosteine ameliorates the harmful effects of ischemia-reperfusion injury on the liver of rats. Acta Cir Bras 2017;32:796-806. [CrossRef]

26. Tejerina T, Ruiz E. Calcium dobesilate: pharmacology and future approaches. Gen Pharmacol 1998;31:357-60. [CrossRef]

27. Garay RP, Hannaert P, Chiavaroli C. Calcium dobesilate in the treatment of diabetic retinopathy. Treat Endocrinol 2005;4:221-32.

28. Jafarey M, Changizi Ashtiyani S, Najafi H. Calcium dobesilate for prevention of gentamicin-induced nephrotoxicity in rats. Iran J Kidney Dis 2014;8:46-52.

29. Brunet J, Farine JC, Garay RP, Hannaert P. Angioprotective action of calcium dobesilate against reactive oxygen species-induced capillary permeability in the rat. Eur J Pharmacol 1998;358:213-20.

\section{DENEYSEL ÇALIŞMA - ÖZET}

\section{Deneysel karaciğer iskemi-reperfüzyon hasarında kalsiyum dobesilatın etkisinin değerlendirilmesi}

Dr. Yılmaz Ünal, ${ }^{1}$ Dr. Berkay Küçük, ${ }^{1}$ Dr. Salih Tuncal, ${ }^{1}$ Dr. Koray Koşmaz, ${ }^{1}$ Dr. Nadir Turgut Çavuşoğlu, ${ }^{1}$
Dr. Kemal Kısmet, ${ }^{1}$ Dr. Mehmet Şeneş, ${ }^{2}$ Dr. Pınar Celepli, ${ }^{3}$ Dr. Murat Durak ${ }^{2}$ Dr. Sema Hücümenoğlu ${ }^{3}$

\section{${ }^{1}$ Ankara Eğitim ve Araştırma Hastanesi, Genel Cerrahi Kliniği, Ankara \\ ${ }^{2}$ Ankara Eğitim ve Araştırma Hastanesi, Biyokimya Kliniği, Ankara}

${ }^{3}$ Ankara Eğitim ve Araştırma Hastanesi, Patoloji Kliniği, Ankara

AMAÇ: Bu çalışmada, etkili bir antioksidan ve antienflamatuvar ilaç olan kalsiyum dobesilatın (CaDob) deneysel karaciğer iskemi-reperfüzyon hasarı (IRI) modelinde koruyucu etkisi araştırıldı.

GEREÇ VE YÖNTEM: Kırk sıçan dört gruba ayrıldı. Grup I'de (sham), sadece hepatik pedikül mobilize edildi. Grup 2'de (kontrol), hepatik pedikül 60 dk klemplendikten sonra 90 dakika süreyle reperfüze edildi. Grup I ve 2'de ek bir tedavi uygulanmadı. Grup 3'te (ameliyat sürecinde CaDob), operasyondan iki saat önce $100 \mathrm{mg} / \mathrm{kg}$ CaDob verildi, 60 dakika iskemi sonrası 90 dakika boyunca reperfüze edildi. Grup 4'te (ameliyat öncesi CaDob), operasyondan önceki 10 gün boyunca $100 \mathrm{mg} / \mathrm{kg} /$ gün CaDob verildikten sonra, hepatik pedikül 60 dakika boyunca klemplendi ve 90 dakika süreyle reperfüze edildi. İşlemlerin sonunda biyokimyasal ve histopatolojik değerlendirme için kan ve karaciğer dokusu örnekleri alındı. BULGULAR: Ameliyat öncesi ve ameliyat sürecinde tedavi gruplarında karaciğer fonksiyon testleri ve doku oksidatif stres parametreleri kontrol grubuna göre anlamlı olarak düşüktü. Ayrıca, kontrol grubundaki histopatolojik hasarın, hem ameliyat sürecinde hem de ameliyat öncesi tedavi gruplarında anlamlı düzeyde azaldığı saptandı.

TARTIŞMA: Kalsiyum dobesilat, antioksidan ve antienflamatuvar etkileriyle ilişkili olarak önemli bir hepatoprotektif etki göstermiştir. Anahtar sözcükler: Deneysel; histopatoloji; iskemi reperfüzyon; kalsiyum dobesilat; karaciğer, oksidatif stres.

Ulus Travma Acil Cerrahi Derg 2018;24(5):391-397 doi: 10.5505/tjtes.2018.33238 